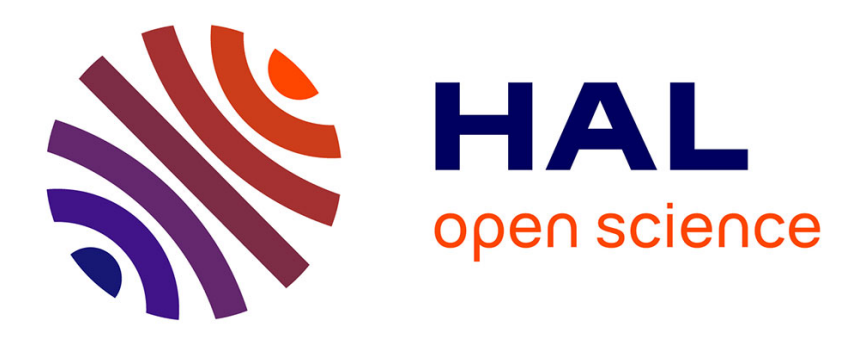

\title{
Against the Tide. Female Property and Political Shift in Late Medieval Turin \\ Marta Gravela
}

\section{To cite this version:}

Marta Gravela. Against the Tide. Female Property and Political Shift in Late Medieval Turin. Mélanges de l'École française de Rome - Moyen Âge, 2018, 130-1, 10.4000/mefrm.3908 . hal03182779

\section{HAL Id: hal-03182779 \\ https://hal.science/hal-03182779}

Submitted on 10 Jun 2021

HAL is a multi-disciplinary open access archive for the deposit and dissemination of scientific research documents, whether they are published or not. The documents may come from teaching and research institutions in France or abroad, or from public or private research centers.
L'archive ouverte pluridisciplinaire HAL, est destinée au dépôt et à la diffusion de documents scientifiques de niveau recherche, publiés ou non, émanant des établissements d'enseignement et de recherche français ou étrangers, des laboratoires publics ou privés. 
130-1 | 2018

L'Armenia nel Medioevo, vettore di mobilità tra Oriente e Occidente (sec. XII-XV) - Beyond their dowries. Women and wealth in medieval and early modern north-central Italy - Varia

\section{Q OpenEdition}

\section{Édition électronique}

URL : http://journals.openedition.org/mefrm/3908

DOI : 10.4000/mefrm.3908

ISSN : $1724-2150$

Éditeur

École française de Rome

\section{Édition imprimée}

ISBN : 978-2-7283-1351-8

ISSN : 1123-9883

Ce document vous est offert par Bibliothèque Diderot de Lyon ENS

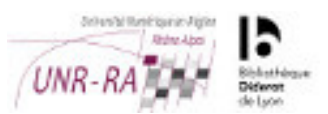

Référence électronique

Mélanges de l'École française de Rome - Moyen Âge, 130-1 | 2018, «L'Armenia nel Medioevo, vettore di mobilità tra Oriente e Occidente (sec. XII-XV) - Beyond their dowries. Women and wealth in medieval and early modern north-central Italy - Varia » [En ligne], mis en ligne le 12 janvier 2018, consulté le 24 juin 2020. URL : http://journals.openedition.org/mefrm/3908; DOI : https://doi.org/10.4000/mefrm. 3908 

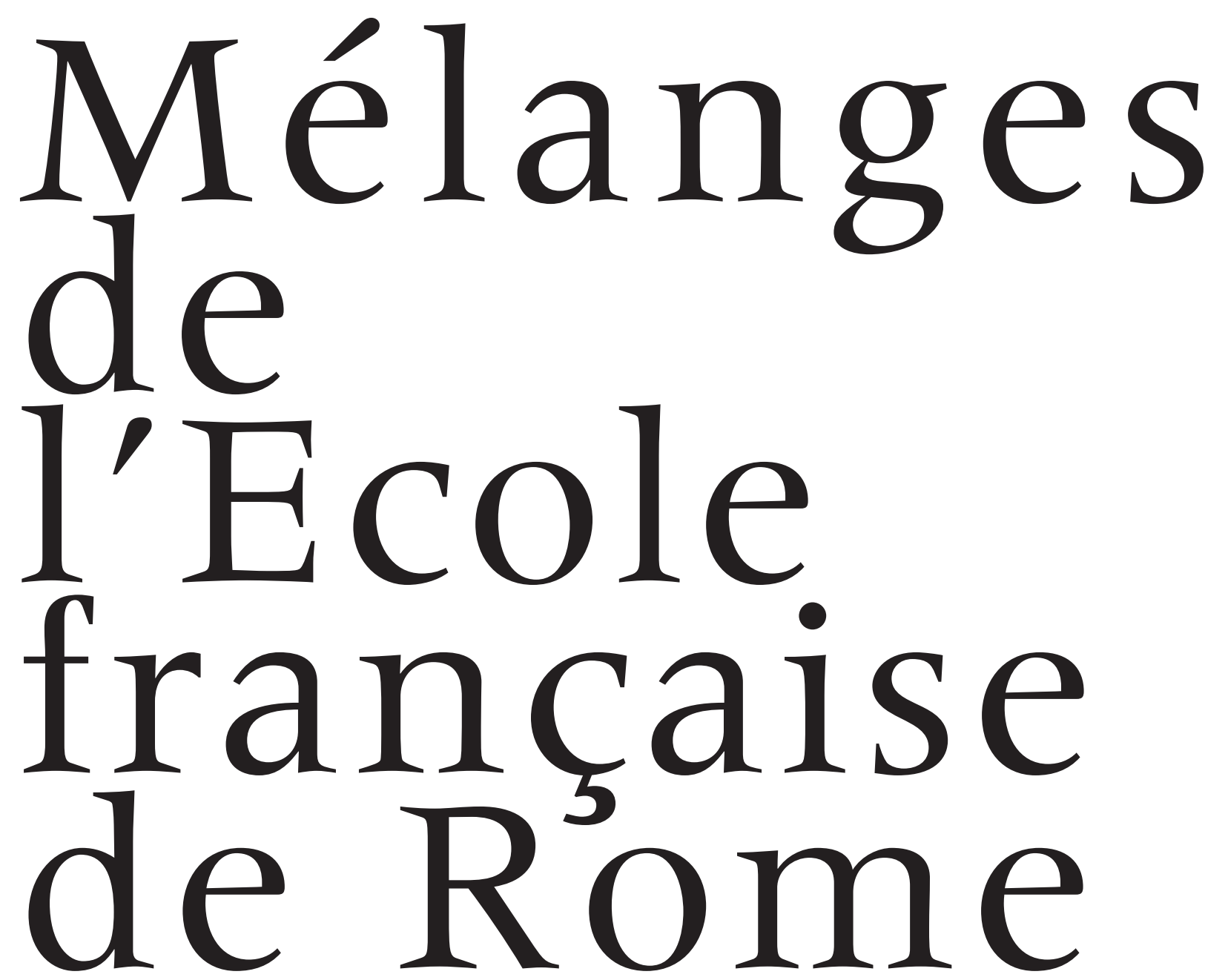

Moyen Âge

MEFRM

130-1 2018 


\title{
Against the tide
}

\section{Female property and political shift in late medieval Turin}

\author{
Marta Gravela
}

M. Gravela, University of Turin, marta.gravela@unito.it

\begin{abstract}
Despite statutory regulations aimed at limiting women's rights over family wealth, late medieval Turinese sources provide a multifarious picture of women as owners or managers of patrimonies, in a range of ownership conditions in which more than just the dowry was brought into play. In addition to bequests from various relatives, in the 14th and 15th centuries women increasingly received significant shares of non-dotal assets and were chosen as universal heiresses in the absence of sons. Through an examination of notarial and cadastral records, this article explores the assortment of succession practices and scrutinizes the process which eventually led to an extension of female property rights in favour of only daughters. It is argued that this legal change resulted from a dramatic transformation in the elite composition in the late 15th century, which allowed the new local government to overcome custom and get a grip on patrimonies through female inheritance.
\end{abstract}

Succession, female agency, Turin, late Middle Ages

In 1489 the city council of Turin approved a significant change to the section of the statutes De servando iure in sucessionibus civium et habitatorum Taurini, which had ruled inheritance since at least 1360, when the statutes were issued. ${ }^{1}$ The clarification of the norm was meant to allow female only children to entirely inherit their parents' patrimony on intestacy. The councillors agreed that - in the absence of sons and of a will - daughters were entitled to all their father's and mother's property, thus preceding other kin:

ipsum statutum sic inteligi debeat videlicet quod si quis vel si qua ab intestato decessit de dicta civitate Taurini $[. .$. nullo facto ordinamento rerum suarum et nullis relictis filiis masculis legittimis ex eo vel a legittime procreatis, relictis tamen filia vel filiabus suis legittimis quod ipsa filia vel ipse filie ipsius sic decedentis succedant et succedere debeant tam in domibus quam in aliis bonis. ${ }^{2}$

1. Statuti 1981, p. 74

2. Archivio Storico della Città di Torino [henceforth: ASCT], Ordinati, vol. 83, fos. 6lv-62v, 67r.
Significantly, the provision was reported as Delibera Statuti [...] ad excludendum agnatos. What led the council to amending this section was the uncertainty arising from the law in the first place, often causing conflicts between heirs, as the notary wrote: pro evitandis rixis litis et questionibus que sepius oriuntur propter diversas oppiniones interpretacionis verborum ipsius statuti. Reported in the book of statutes - though not officially approved by the Duke of Savoy until the 17 th century $-^{3}$ this amendment was clearly in contrast with the development of the inheritance systems of most other Italian cities, where women were increasingly excluded from access to wealth, ${ }^{4}$ with few exceptions such as Pisa. ${ }^{5}$ Despite the large number of disputes still reported in those years, this

3. ASCT, Ordinati, vol. 173, fos. $71 \mathrm{v}-74 \mathrm{r}$. In this occasion (1622) the council extended female succession rights to sisters whose brothers had died without heirs.

4. Chabot 1996. This decision was in contrast with most of the laws and legal thought of the rest of Piedmont as well, see Pene Vidari 1986; Duboin 1831, p. 335-336.

5. See Duval 2018, in this issue. 
decision shows a peculiar attitude towards female property rights, not only acknowledging what was often taking place in practice already, but also suggesting that something had happened to enable such a legal recognition against the prevailing tide of the Italian context.

The present research aims at understanding the process which led to this change, through a study on female access to family wealth in late medieval Turin. This article will explore the incidence of transmission of non-dotal assets to women, and female participation in the management of possessions in the 14th and 15th centuries. Furthermore, I will assess the significance of the 1489 provision guaranteeing daughters' inheritance: to what extent did it actually protect female rights ensuring wider agency or, rather, make it easier for husbands to take over the patrimony? These questions lie at the core of the possibility to examine the female condition in late medieval societies, with particular reference to the Italian urban context.

Following the pioneering works by Christiane Klapisch-Zuber ${ }^{6}$ on Florentine families, which first focused especially on women, studies on female property rights and agency have flourished in the past decades, benefitting from different approaches which merged law, social history and anthropology. Among Italian cities in the late middle ages, though, mainly Florence and Venice, and to some extent Genoa, have been thoroughly taken into account, whereas the rest of the picture remains widely unexplored. ${ }^{7}$ Florence and Venice represent the main references in historical studies, thanks to their divergent situations: the former characterized by a strong patriarchal system in which women were increasingly excluded from management of family assets, the latter allowing women wider agency and participation in family life. This opposition has been partially revisited by scholars: on the one hand, reconsidering Florentine women in

6. The most relevant contributions were collected in KlapischZuber 1985.

7. Key studies on Florence: Kuehn 1991; Molho 1994; Chabot 2011; Kirshner 2015. On Venice see Chojnacki 2000; Crouzet-Pavan 1992, p. 373-462. On Genoa Hughes 1975, 1978. Some features of women's role in Genoa have been recently revisited in Bezzina 2015, p. 137-170. For other cities see also Cohn 1988, p. 146-158; Cavaciocchi 1990; Calvi - Chabot 1998. A more comprehensive account on these studies is provided by Kirshner 2015, p. 14 and Chabot 2006, p. 268-270. the light of the contrast between law and practice, which provided evidence of women as full-fledged social and legal actors; on the other hand, reassessing the rights granted to Venetian women as a different way to exclude them from the largest part of the family patrimony.

Several studies show how the late middle ages saw a serious worsening in women's autonomy, with a dramatic restriction since the 12th century of their spaces of action not only regarding the possibility to exert power, but also work and, more generally, what was traditionally perceived as the public sphere. ${ }^{8}$ Nevertheless, the redefinition of the concepts of public and private in the late middle ages led to the enhancement of the public significance of patrimony and kinship, prompting scholars to analyse the role of women in citizenry through family, social and patrimonial ties and their relationship with power. ${ }^{9}$ Transmission of property and kinship relationships are therefore the key to female agency and their role within the family and society. Nevertheless, these issues were strictly connected not only to economic and demographic factors, but also to political structures and transformations.

The article will therefore look at women's non-dotal possessions in the light of the role played by the local government and the seigneurial authority in family matters. The first section will thus take into consideration the legal and political framework in which women acted, and the sources to examine their role in Turin. The second section will scrutinize data regarding women as heiresses of non-dotal assets - from gifts and bequests beyond the dowry to the entire family patrimony in order to understand what kind of possessions they were given, by whom, in which ways, and whether all this depended on social class or not. Finally, the third section will examine margins of female agency within the family and the kindred:

8. Guerra Medici 1996, p. 19; Cammarosano 1977; for an account on legal and historical studies on this theme see Menzinger 2012, p. 119-122.

9. Howell 1988; Muzzarelli 1998; Seidel Menchi - Jacobson Schutte - Kuehn 1999; Meriggi 2004; Kirshner 2004, 2006; Ferente 2014. 
to what extent did inheritance give women the possibility to manage their assets and what role did they have in the administration of family wealth?

\section{POLITICS OF PATRIMONY: LAW AND SOURCES}

Included in the Savoy lordship since 1280, Turin was a small town, with an average population of 4.000 people until the mid-15th century. ${ }^{10}$ Nonetheless, its geographical position and the episcopal see made it to some extent the pre-eminent centre of the region, which lacked large cities. However, it was not until the late 15th century that it became the political and administrative heart of the area, then in the following century the capital city of the entire Duchy. Its long-time limited political role implies an irregular presence of the lords, who mainly resided in Chambery or Pinerolo, being physically and politically distant from Turin until at least the mid-15th century.

Turin was therefore controlled by seigneurial officers who represented the prince, exercised executive power, supervised princely accountancy, administered justice and superintended the activity of the city council, whose autonomy was consequently restricted. ${ }^{11}$ Neither the officers nor the council ever directly intervened in family affairs. In this perspective, this research aims at showing how, notwithstanding the strongly patriarchal system, the vagueness of law on some crucial themes and the lack of interference "from the top" before 1489 resulted in wider autonomy for the families regarding their private matters, consequently ruled by custom. Rather than promoting a straightforward arrangement regarding property devolution and female agency, the law charged families with the responsibility of regulating these issues, so that in some kindreds women were precluded from exerting any economic power,

10. Gravela 2017a, p. 55.

11. Comba 1997; Barbero 1995. For a recent synthesis on the Duchy of Savoy between the late medieval and early modern period see Barbero 2014. whilst in others they could receive significant parts of family wealth and experience more freedom from patriarchal constraints.

As highlighted by legal studies, private law is almost absent from the 1360 Turin statutes, in which only three among the 331 articles dealt with inheritance and women's rights. ${ }^{12}$ The article XXXVIII (the De servando iure previously mentioned) established the respect of Roman laws of succession, granting equal division among all children, males and females. ${ }^{13}$ In case of the father's death $a b$ intestato law only gave precedence to agnates over strangers as far as houses were concerned, without either a reference to the rest of the patrimony nor a definite explanation of the succession line. ${ }^{14}$ It is not until article CCCXXV (Quod filia maritata habens fratres, decedente patre vel matre ab intestato nichil possit petere) that we find out that in the event of intestate death of parents a dowered daughter could not claim another inheritance share, abiding by the exclusio propter dotem common in all Italian city-states and to the exclusio propter masculos. ${ }^{15}$ The exclusio propter masculos in Turin entailed that, once the dowry was provided by either father or mother, also maternal assets were allocated to sons on intestacy. Thus, these two articles implied equal division among heirs, preference for kin over other people and for sons over daughters, but did not take into account all the possible cases of conflicting heirs, especially those arising from the presence of daughters without brothers, which later required a clarification. Finally, a third article, XXXIX (De dote remanenda marito pro medietate) established that, if the wife predeceased her husband without leaving any children, the man could retain half her dowry, even if she had children from a previous marriage. ${ }^{16}$

As a result, women's rights over family wealth were restricted on intestacy, a condition which involved the vast majority of cases, considering

12. Barbero - Pene Vidari 1997, p. 249.

13. Statuti 1981, p. 74; Bellomo 1961, p. 163-185.

14. On law regarding intestate succession in early modern Piedmont see Mongiano 1990.

15. Chabot 2011; Statuti 1981, p. 135: ipsa talis filia maritata et dotata stantibus et superstitibus filiis masculis et fratribus ipsius filie aut filiis ipsorum fratrum ipsa filia non possit ab intestato subcedere patri vel matri [...] sed sit contenta de dote sibi data. On the exclusio propter dotem see Kuehn 1991, p. 238-257 and for southern France Mayali 1987.

16. Statuti 1981, p. 74. 
that few people made a will. Since the daughters' share was normally delivered through the dowry, division of inheritance was never actually equal, and law itself, as in other cities, was aimed at reducing the chances of dispersal of wealth through female inheritance. ${ }^{17}$ Nevertheless, unlike the other cities, Turin statutes remained extremely vague on several matters concerning marriage, lines of succession and legal capacities of women, and - except for 1489 - were never updated according to demographic and economic changes or government needs, so that they were still in effect in the 19th century, when they were finally replaced by the law of unified Italy. ${ }^{18}$ Even when the Decreta Sabaudiae Ducalia were promulgated by Amedeo VIII in 1430, Turin statutes remained valid and coexisted with the ducal law. ${ }^{19}$

It is beyond the purpose of this article to provide a thorough comparison between Turin and the major Italian cities in terms of institutional control over family affairs; however, a few data can provide elements to outline the strikingly different framework, besides the simple difference in scale of the city. The Florentine statutes increasingly included a long series of rules regarding female rights in relation to property and more generally family law. ${ }^{20}$ Not only did they discipline succession in the attempt of excluding women, providing detailed lists of heirs according to various possible situations, but they also maintained supervision of men over women in legal transactions, through the roles of the procurator and the Lombard mundualdus, a rule common to several other Italian cities. ${ }^{21}$ In addition to law, increasingly oriented towards a protection of women and limitation of their rights between the 14th and 15th centuries, the creation of the Florentine territorial state entailed a strong political intervention in the private sphere. Since the late 14th century governments aimed at reinforcing patrilineage and moral order through the establishment of offices entrusted with the guardianship of orphans, women's respect for sumptuary laws, suspect behaviours of young men, and the

17. Niccolai 1940.

18. Bizzarri 1933, p. XLVIII-LI.

19. Decreta Sabaudiae.

20. Kuehn 1991, p. 241-243; Chabot 1998.

21. Kuehn 1999, p. 436-437, 451; Kuehn 1991, p. 212-237; Fisher 2009; Kirshner 2015, p. 161-188. institution of the Monte delle doti, dowries funds. ${ }^{22}$ Legal reforms concerning family assets need to be examined in the light of the construction of governing elites and their financial needs. ${ }^{23}$ The Florentine financial crisis enhanced the development of this system, as orphans' inheritances and savings for dowries were invested in the city's public debt. ${ }^{24}$ Similarly, correcting the legal apparatus in order to limit women's opportunity to inherit was always aimed at strengthening the governing elite.

The (supposedly) opposite situation of Venice implied that daughters had higher chances to obtain family assets, but the inheritance system was not actually equal: sons and daughters received equal shares only of the maternal possessions, whereas division of the paternal was strongly unbalanced. ${ }^{25}$ Despite the fact that the statutes admitted daughters as universal heiresses in the absence of sons (more explicitly than in Turin), this option was highly unlikely because fathers often made wills in those cases. ${ }^{26}$ Daughters could possibly inherit entire patrimonies on intestacy only from their mothers, their fathers being concerned with transmission of their wealth to their agnatic kin for political reasons. However, mothers dowering daughters in their wills automatically excluded them from inheritance due to the exclusio propter dotem. The need to preserve large patrimonies, as they were functional to the political stability of the elite, resulted in a system entailing dowry and bequests as a means to exclude daughters from the rest of the inheritance.

In Milan, Pavia and other cities in Lombardy late 14th-century statutes - reprising 13th-century redactions - disciplined succession in detail, ensuring that on intestacy women were bypassed by a huge number of male kin, up to the seventh degree of kinship in Milan. ${ }^{27}$ Succession to mothers and of spouses to each other was also thoroughly regulated with the aim of reducing the risk of dispersal of goods to the agnatic line. Succession laws further expanded in the late 15th century

22. Calvi 1994; Chabot 2010. On the Monte, Kirshner - Molho 1978.

23. Bellomo 1961; Chabot 2010.

24. Chabot 2010, p. 199.

25. Chojnacki 2000.

26. Crouzet-Pavan 1992, p. 419; Guzzetti 1998.

27. Kuehn 2015. 
in the impossible attempt to comprise all possible inheritance scenarios and at the same time new solutions were found by the nobility to exclude women from succession, such as recurring to the fideicommissum in wills. Despite the absence of the mundualdus, the increasing control over women's assets and agency is proven by the introduction of limitations to female legal capacities in the late 15th-century statutes: no economic transaction above a certain sum could be carried out by a woman without her husband's or agnate's consent. $^{28}$

In this respect the absence of similar constraints and institutions in Turin was not exclusively due to its size and political marginality, but was also connected to the amount of patrimonies, the fiscal policies adopted by the city government, the lack of ducal intervention and the long-time stability of the local ruling class. Despite its serious financial difficulties in providing resources to fulfil the demands of the lords of Savoy, the commune never opted for a system based on irredeemable debt, as several city-states did in the late 14th century. ${ }^{29}$ As a result, there was no need to get a grip on family assets to secure the financial coverage of the city, which was granted by individual loans and purchase of excise income.

Moreover, the lords of Savoy were never directly involved in regulating family life: this obviously did not imply a total lack of control over sexual and social behaviours, since subjects such as prostitution, rape and concubinage were instead taken into account either by the local statutes or the Decreta Sabaudie, and authorities tried to limit sex-related crimes. ${ }^{30}$ Nevertheless, local and superior authorities never really seemed capable nor interested in regulating family matters. In a number of other Italian cities the statutes forbade, or at least sanctioned, marriages between rich local women and foreigners, in order to prevent the loss of fiscal income. ${ }^{31}$ Notwithstanding a certain degree of social blame, in Turin there is no sign of laws aiming at forbidding this practice, as taxes

28. Kuehn 2015, p. 423-424.

29. On the financial system established in Turin to support the city and the lords of Savoy see Gravela 2014.

30. Statuti 1981, p. 114, 118; Decreta Sabaudiae, fos. CXXXIIICXXXIIII; Comba 1986.

31. Storti Storchi 1985, p. 24-25; Kirshner 2015, p. 161-188. were due on the property owned in the city district regardless of residence, so that several women, even of the political and economic elite, married foreigners and left the city. ${ }^{32}$ A foreign husband seemed a more frequent option especially for remarriages, as in several cases involving widows of the upper social strata who left their children with their paternal kin, remarried and moved to other villages and towns of Piedmont. The reason for this may lie in a marriage market within the city too limited for elite families, in particular for nobles aiming at securing through their daughters and sisters valuable alliances, mainly aspiring to feudal lords, officers and rich professionals of the principatum. These marriage strategies matched those of the most influential noble male citizens, who also tended to bind to rural seigneurial lineages. ${ }^{33}$ In this respect, no significant interference of the princes and dukes is known, contrary to what was happening for example in the Duchy of Milan. ${ }^{34}$

As for the local government, the structure of the political elite granted an alternative form of control over family patrimonies. The Turin elite was in large part formed by extended noble kindreds, groups of lineages with a common ancestor and surname, and by a few non-noble families, often linked to the former through marriage or economic ties. The long-lasting presence of this group at the top of society resulted in a general control exerted by the kindred over families and their wealth. As long as large and cohesive kindreds survived, women were unlikely to gain significant portions of the family patrimony beyond their dowry, though they could take part in the management of property, as we will see in the third section. We will see that the first attempts to get around this unwritten rule were often unsuccessful due to the strong interference of paternal kin, and prompted fathers to secure their daughters' rights through wills and choices of specific heirs. I will argue that the disintegration of this elite and its replacement by a new ruling class first caused a series of conflicts

32. It is interesting to note though that the statutes forbade the sale of property to foreigners (article CCI), but did not even mention the event of a marriage to a foreigner. Statuti 1981, p. 106.

33. Gravela 2017a.

34. Leverotti 1994, p. 138; Arcangeli 2012; Gamberini 2017, p. 104-106. 
between heirs and subsequently made it possible to clarify the content of law in order to limit the intervention of distant kin in daughters' succession. ${ }^{35}$

This study on women's non-dotal assets and agency was carried out by scrutinizing two main sets of sources in addition to law: notarial records and cadastral registers. The former - dating back to the 13th to 15th centuries - include wills in the first place, essential to examine decisions as far as succession was concerned, and various types of contracts involving women and their property, which offer an insight into the actions women performed independently or jointly with men. The cadastre made it possible to go beyond legal provisions and testators' intentions, by verifying the actual transmission of assets over time. This source, available from 1349 onwards and produced every eight years on average, provides data regarding all women included in the lists of tax-payers and their property, showing a huge variety of cases in which women owned wealth, sometimes becoming household heads. As a result, the cadastre allowed me to examine socially transversal choices and practices, rather than just the behaviours of those families who were more likely to make wills. Female presence in the cadastral registers proves the existence of different behaviours not only between social classes, but also within the same class and sometimes within the same kindred depending on the lineages, their wealth and different attitudes according to the generations.

\section{FEMALE OWNERSHIP}

Abiding by law and custom, the exclusio propter dotem and propter masculos prevailed in Turin. As a general rule, women obtained the dowry and frequently the trousseau at the moment of marriage: in Turin dowries were considerably lower than in the major Italian cities - the richest no higher than 500 florins in the 15th century whereas the trousseau usually included bedsheets, blankets, jewels and so on. This information is

\footnotetext{
35. On the end of the political elite Gravela 2017b.
}

provided not only by dowry contracts, but also by husbands' wills which established the conditions for refunding their wives in case of widowhood. Nevertheless, women always received other possessions from their parents, their husbands and other relatives throughout their lives. In what follows I will first give an account of these gifts and bequests, then of larger shares of inheritance, showing how, as far as female ownership was concerned, practice anticipated wills and legal acknowledgment in the 15th century.

Analysis of non-dotal assets has been hampered by limited details regarding the legal status of the various portions of wealth. There is no trace in the local statutes of rules concerning paraphernalia and bona non dotalia, no indication of who was entitled to use them, no sign of contracts to define wives' rights except those of dowries. As in Florence, the trousseau was likely to have replaced what used to be the paraphernalia: movable goods brought by the wife mainly for her own and her husband's joint use. ${ }^{36}$ This hypothesis seems confirmed by the statements of several women, who claimed their husbands had spoiled the goods they had brought into their new home. Nevertheless, other types of bequests were also given to women regardless of their definition. In 1380 a woman clearly spoke of additional possessions to the dowry and the paraphernalia: her father had bought a house with the intention of leaving it to her together with the paraphernalia, but her husband had illegally included it in his fiscal statement. ${ }^{37}$

Wills show differences in bequests by men and women, as already highlighted by several studies which describe female wills as more "crowded». ${ }^{38}$ Turinese women were more likely to distribute their wealth to a large number of other women: even when a mother appointed her son as heir, several other bequests could deprive him of a huge part of the inheritance. This is the case of Giacomina, widow of Oddone Peagerio: despite the choice of her son Antonio as universal heir in the 1318 will, she handed out to her six married daughters either land or money. ${ }^{39}$ In total Antonio received four iornate

36. Kirshner 2015, p. 75.

37. ASCT, coll. V, vol. 1034, f. $28 \mathrm{r}$

38. On women's wills see the studies collected in Rossi 2010 and on Venice Guzzetti 1998.

39. Archivio Arcivescovile di Torino [henceforth: AAT], sez. VI, prot. 4 , fos. $56 r-58$ r. 
of land (one iornata corresponding to $3810 \mathrm{~m}^{2}$ ), a third of the house, a third of a farmhouse and a third of a vegetable garden, whereas his sisters - all dowered already - altogether got six iornate of land and 30 lire, and other land and money were given to Giacomina's four granddaughters, a son in law and a servant. Women's wills were often aimed at reducing inequalities between sons and daughters resulting from the exclusio propter dotem. In this will we find out that most of Antonio's share was actually his father's property; Giacomina thus used mainly her own assets and what she got from her husband to increase her daughters' portion and make other bequests.

The other female wills show a similar pattern: women spread their possessions among several people, trying to rebalance gender inequalities, favoured their own kindred in spite of their husband's, and expressed gratitude and affection to people who had worked for them. In this respect, it is worth noting that daughters, granddaughters and nieces were more likely to receive land, jewels and personal objects from the trousseau, whilst servants usually obtained sums of money. Houses were never involved in this distribution: since they represented the family patrimony and embodied the lineage identity, they were always given to men (unless women were only children, as in the aforementioned example). That is why the statutes only mentioned houses as far as intestate succession was concerned.

Male wills display a more limited series of relationships: their bequests to women were much smaller and limited to wives and daughters, rarely reaching granddaughters. Whilst bequests to daughters were usually aimed at increasing the amount of money or property forming the dowry, wives could actually benefit from extra shares in addition to the refund of their dowry and trousseau. In 1295 Albertino della Rovere, one of the most distinguished members of the local elite, appointed his sons as universal heirs, but established in his will a series of bequests to his daughters and wife Filippa. The woman was chosen as the children's guardian and in addition to the dowry and trousseau received 25 lire, 14 iornate of land and a vineyard, a house and yearly food in case she later preferred not to live with her sons. ${ }^{40}$

40. Cognasso 1914, p. 394-396.
These bequests were clearly aimed at granting her safety throughout widowhood, but after her death all possessions had to revert to the universal heirs: in his will Albertino planned succession in detail, thus reducing Filippa's rights to usufruct, although the notary never used this word.

Notwithstanding unequal numbers of wills for different periods, ${ }^{41}$ it is clear that until the mid-14th century the likelihood that women inherited significant shares of family assets was dramatically low. Especially in the nobility and the most important elite kin groups, wills prove how avoiding dispersal of patrimonies through women was a primary concern: in the absence of sons, the testators appointed male kin as universal heirs, with an obvious preference for brothers when available. The will of the canon priest Guglielmo da Cavaglià is adamant in this respect: in 1335 he chose some kinsmen as universal heirs, under the condition they did not split the inheritance nor transfer his wealth to women, with particular reference to houses..$^{42}$ Not a single example of an heiress is known for this period, when kinship groups maintained a strict control over family assets. Because of the loss of the early 14th-century cadastral sources, it is impossible to check whether some people managed to get around kinship control over patrimonies.

This situation underwent the first changes after the mid-14th century, when women started appearing in wills and cadastral registers as heiresses. A series of plagues in 1348-50 and again in 1361 overturned demographic structures in Turin: as a result, in 1363 more than $17 \%$ of the enrolled taxpayers were women, alone or with young children. ${ }^{43}$ The plague was certainly a major factor in reducing the number of kin interested in the inheritance; however, this cannot be assumed as the only reason for such a remarkable change. The preference men showed for their daughters and wives did not exclusively depend on the absence of kinsmen. In 1361 Vittorio Prandi, member of a prestigious family, made a will appointing his

41. The analysis includes 37 female (15 from the 14th and 22 from the 15th century) and 77 male (respectively 28 and 49) extant wills of Turinese citizens, scattered among various archival fonds.

42. Archivio Capitolare di Torino [henceforth: ACT], Pergamene, n. 126.

43. Gravela 2017a, p. 60. 
only daughter Florina as heiress, despite her being already married and having received her dowry at least since 1349, and Vittorio having a male as close kin. ${ }^{44}$ Similar cases emerged in the following decades: before becoming a recurrent option in wills, female inheritance in the presence of agnates frequently appeared in practice, as proven by the cadastre, which suggests that women had sometimes benefitted from intestate succession.

If access to family wealth was easier for women of lower social strata, significant examples also involved women in large noble kinship groups. At the moment of death, the noble Savoy officer Enrico da Gorzano did not have any sons: his widow Margherita and their daughters Caterina, Leonetta and Violanda entirely inherited his patrimony. Caterina and Leonetta got married to two elite members and received their dowries, trousseaus and certainly some other goods, because in 1379 we find Leonetta gifting her sister 50 florins, without any mention of her husband nor other men, implying she was using her personal property. ${ }^{45}$ The following year Margherita was enrolled in the cadastre as an autonomous taxpayer: at this date she still had most of her husband's assets and specified what was hers and what was Violanda's, who was still under age and living with her. The widow had 26 iornate of land, half the family house and a significant amount of movable possessions, Violanda other 26 iornate of land; their patrimony was almost identical to Enrico's, thus clearly matching his inheritance and not just possessions forming their dowries. ${ }^{46}$

Enrico's succession choices were part of the approach to female rights and agency put in practice by the da Gorzano: this kinship group stood out for the involvement of women in its patrimonial affairs. One fourth of the fiscal entries in the cadastre between 1349 and 1493 pertained to a woman, often a widow, but occasionally a wife acting with her husband; moreover, men were more likely to specify which possessions were their wives' property, a behaviour never observed in other noble lineages. ${ }^{47}$ Despite the fact that male control was never really absent, we will see in the next section that women of the da Gorzano had wider agency, agnates rarely interfering when female relatives were playing an active role in managing assets.

It is no exaggeration to say that since the late 14th century, choosing women as universal heiresses increasingly became an important alternative to kinsmen, first in the lower social strata - where kinship groups and patrimonies were smaller, thus the risk of interference by relatives lower - then in elite families. A series of wills shows men's preference for their daughters and wives in the absence of sons, a decision not always accepted by male relatives, which resulted in harassments against legitimate heiresses, as appeared by matching this information with data provided by other sources.

Even in the same social strata and kinship group different attitudes towards female inheritance could coexist, proving that the chance for women to get access to family wealth and actually manage it did not exclusively depend on social class. This is particularly clear if we follow the various lineages of the Alpino, one of the most ancient kinship groups in Turin, vassals of the bishop since the consular period, listed among nobility (hospicia) at least since 1193 and with some lineages holders of a fief in the rural district. ${ }^{48}$ Despite their rank, the Alpino had an extremely heterogeneous social profile, including milites, notaries, jurists, landowners and innkeepers. Antonio Alpino, an innkeeper and occasional moneylender who also owned houses in the city and land, had three children who survived until adulthood, a son and two daughters. ${ }^{49}$ As his only son became a priest, though, his wealth was entirely transferred to his widow and daughters, partly before his death. When she first appeared in the cadastre, the eldest daughter Agnese was already a widow and had remarried to a rich butcher and cattle breeder, bringing into his patrimony her dowry. In 1363 her father secured her own property by presenting a separate fiscal statement for her, including a small house and 29 iornate of land, her share of inheritance. ${ }^{50}$ After his death in 1383, the widow Alaxina received another house and seven iornate of land, whilst the
44. ACT, Pergamene, n. 727.

45. AAT, sez. VI, prot. 16, f. 9r.

46. ASCT, coll. V, vol. 1034, fos. 76v-77r.

47. Gravela 2017a, p. 146-148.
48. Bordone - Fissore 1997, p. 498; Casiraghi - Artifoni Castelnuovo, p. 711-712; AAT, sez. VI, prot. 1, fos. 41v-42v. 49. ASCT, coll. V, vol. 1022, fos. 61v-62r; vol. 1027, fos. $2 \mathrm{r}-2 \mathrm{v}$.

50. ASCT, coll. V, vol. 1028, fos. $8 \mathrm{r}-8 \mathrm{v}$. 
rest of the patrimony - three houses, nine iornate of land and income from rents - passed on to a younger daughter, Giorgia. ${ }^{51}$ Giorgia lived on her own until the 1420s, also receiving bequests from her father's relatives. ${ }^{52}$ She always appeared in the sources as an independent legal actor: in fiscal sources; in court when she reported damages to her land property; when she was asked to take part in small loans to the city council, as her father had used to do. ${ }^{53}$ Eventually, in 1420 she drew up a will, leaving her whole patrimony to her nephews ex sorore (Agnese's sons) instead of her paternal kin. ${ }^{54}$ This case proves how, even at a higher social rank, the patriarchal system could leave agency margins to women depending on their father's decisions and their respect by agnates.

This attitude of fathers was not necessarily linked to the "socio-professional» profile and wealth of the family, rather the result of a series of choices in which the reproduction of the lineage was not perceived as the absolute priority, as it was instead in the vast majority of cases. Despite his clearly higher status, as he was among the holders of the fief, another member of the same kinship group, Michele Tommaso Alpino, showed a similar approach to women's rights: his wife's property was described in detail in his fiscal statement, instead of being indistinctly included in the household assets, and other taxpayers mentioned both spouses as neighbours, rather than just the husband as it usually happened..$^{55}$ Furthermore, Michele Tommaso, lacking a male heir, appointed his two daughters as universal heiresses in 1415 , another case showing how this option was far more concrete than the legislators had expected and suggests that the 1489 council resolution mentioned in the opening lines was a reflection of an already existing practice. ${ }^{56}$ However, Michele Tommaso's daughters were not as lucky as their

51. ASCT, coll. V, vol. 1036, f. 94r; vol. 1133, f. 41r; vol. 1038, f. 11v; vol. 1043, f. 12v.

52. ASCT, coll. V, vol. 1133, f. 33v.

53. ASCT, Carte Sciolte, n. 3212/4, f. 38v; Libri consiliorum 2006, p. 25, 334.

54. Archivio di Stato di Torino [henceforth: AST], Sez. riunite, Archivio Storico dell'Ospedale Maggiore di Torino [henceforth: ASOMT], 1.1.5, 8.2.1 / 8, n. 15; 1.1.5, $9.5 / 9$, n. 51.

55. ASCT, coll. V, vol. 1044 , fos. $78 \mathrm{v}-80 \mathrm{v}$; vol. 1133 , f. $56 \mathrm{v}$. Martina de Crovesio, Michele Tommaso's wife, had received non-dotal assets especially from her mother.

56. ACT, Pergamene, n. 514. relatives Agnese and Giorgia, as in 1428 their uncle appeared to have taken possession of their inheritance. ${ }^{57}$

Despite the resistance of agnates, though, the idea that women could inherit made its way among Turin families. This led to two main novelties in the 15th century: on the one hand, notarial records displayed a new vocabulary of rights, in which ius institutionis coexisted with ius naturae; on the other hand, fathers tried to protect their daughters from kin interference by recurring to more complex inheritance strategies, mainly appointing sons-in-law as heirs in their wills, alone or jointly with their daughters.

As previously stated, neither law nor politics actually took into consideration female rights in detail by regulating the administration of non-dotal assets; as a result, no clear definition or rule regarding the "legittima" is known..$^{58}$ Nevertheless, in a series of early 15th-century deeds notaries stressed the importance of natural rights over family assets: of children of both sexes over their mother's dowry, of dowered daughters over additional possessions (daughters who got the dowry iure institutionis et qualicumque legitima porcione sibi pervenire debenti iure naturali), ${ }^{59}$ but most of all of only daughters over the entire patrimony. In 1432 Caterina Mazzocchi claimed her rights over her father's inheritance sciens et certifficata ut asserint quod hereditas dicti quondam Bartolomei sui patris universaliter et in solidum ad eam tamquam filiam unicam pertinet iure nature. ${ }^{60}$ It is hard to say whether notaries played a role in rephrasing and reshaping these rights; yet this vocabulary proves how female rights were perceived in Turin society, showing the cracks of a supposedly strict patriarchal system.

However, the presence of a will and the wider acknowledgment of female rights was not enough when testators had male relatives interested in their wealth. In the first half of the 15 th century we find an unprecedented solution in fathers' wills: sons-in-law were appointed as heirs, alone or jointly with their daughters, sometimes even equally with a son, in order to prevent disputes

57. ASCT, coll. V, vol. 1049, fos. 49v-50v; vol. 1055, fos. 60r-61r.

58. Kuehn 2012; Mongiano 1990, p. 51-57.

59. AAT, sez. VI, prot. 28, fos. $115 \mathrm{v}-117 \mathrm{r}$.

60. AAT, sez. VI, prot. 29 , fos. $52 \mathrm{v}-53 \mathrm{v}$. 
and secure their daughters' future. Presumably with the intention of avoiding such conflicts, in the 1420s the noble Francesco Borgesio arranged his daughter's marriage to a distant relative, Martino Borgesio, appointing them both as universal heirs in his will, in order to secure their rights from agnate's claims. ${ }^{61}$ Actually, their patrimony seems to an extent under control of Francesco's widow, as she was the owner of most of the land (more than 150 iornate) in 1436 and was still in charge of delivering the couple's fiscal statement in $1445 .{ }^{62}$

Gradually the presence of daughters and wives in wills increased. Sometimes due to the lack of agnates, sometimes also in presence of them, men preferred their next of kin regardless of gender. However, women only stepped in when sons were not available, as explicitly prescribed by Giacomo Zucarello in his 1434 will: he appointed as universal heir the ventrem eius uxoris, explaining that if the child they were expecting was a male he would have been his heir; if the child was a female instead she was going to be his heiress equalibus portionibus with her older sister. ${ }^{63}$ As a result, the growing number of heiresses in 15th-century wills must not be mistaken for a general preference over men: the fact that more and more people drew up a will in favour of a woman most probably unveils the attempt to secure succession choices in the absence of sons, whereas in case one or more sons survived the need to make a will was less urgent. This seems confirmed by a similar pattern in inheritance choices in other parts of Piedmont, where heiresses appeared in large numbers in the same period, sometimes all of a sudden. In the nearby town of Chieri for instance several 15th-century wills mentioned only daughters as heiresses; likewise wills with heiresses came out in the notarial records of the bishop's curia drawn up in villages of southern Piedmont in the late 15th century. ${ }^{64}$

As we have already seen, in Turin this choice first spread among families at a lower social level, which were smaller and less likely to fear harassment by agnates, whilst similar attempts in noble families were not always successful. This practice became more common since the mid-15th century

61. ACT, Pergamene, n. 117

62. ASCT, coll. V, vol. 1055, fos. 2r-3r; vol. 1064, fos. 3r-4r.

63. AST, Sez. riunite, ASOMT, 1.1.5, 8.4/8, n. 20 bis.

64. Barale 2011; AAT, sez. VI. for two main reasons: on the one hand thanks to the gradual breakdown of the ancient and large kinship groups forming the bulk of the elite, which lost several lineages and became impoverished on demographic grounds; on the other hand, because new inhabitants rarely had a large family with them and were thus closer to their own household members. A higher number of men appointed as heiresses their daughters and wives rather than distant kinsmen, who sometimes did not even live in the city. The remarkable feature of wills in Turin lies in the limited degree of planning displayed by testators, who (especially women), even in the 15 th century, rarely resorted to the fideicommissum. ${ }^{65}$ Unlike what happened in Venice, Tuscany or even in Chieri, where female inheritance was frequently contemplated, but often used as a means to reach subsequent male heirs through the fideicommissum, in Turin most heiresses were free to dispose of their property ${ }^{66}$ Or rather, the testators chose heiresses without binding family assets to specific succession lines after them; we will see in the next section to what extent these women were actually able to decide how to use wealth.

According to the council provisions, this process led to a series of conflicts between legitimate and alleged heirs, which prompted the local government to amend the statutes and clarify the norm following practice. Mid-late 15th-century Turin had actually gone through a considerable expansion and significant social transformations, due to the establishment of a new university and the ducal council in town, to the extinction of most of the lineages at the top of society and the arrival of several new inhabitants. ${ }^{67}$ This caused an unprecedented instability of local political institutions, much more open to new citizens than in the previous two centuries, when places in the council were allocated to a limited number of families. As a result, the council of 1489 had little to do with that of the previous period: rather, it was the result of the dissolution of the medieval elite, gradually replaced by new citizens with a different social and political profile. The disputes over female inheritance were to an extent disputes between old and

65. Unlike what emerged from Chauvard - Bellavitis - Lanaro 2012.

66. Lanaro 2012.

67. Gravela 2017b. 
new families. The 1489 decision was taken by new councillors: only a turnover in the council could have made it possible to abandon custom and revise the law in favour of women, showing how this was in fact a political decision.

Not only does this change prove the collapse of a society essentially based on noble kindreds, but also the detachment of households from wider kinship groups and the strengthening of their internal bonds. A striking example of this dates from 1499, when the lawyer Antonio Maraffino chose his second wife Caterina as universal heiress, despite having a few relatives in Turin: this is totally in line with similar examples from the previous decades. What makes this will absolutely unique for this period is that Antonio explicitly considered the possibility that Caterina remarried and approved it; while establishing she had to live as a widow for a year, he then allowed her to remarry and stay in the family house with her new husband. ${ }^{68}$ Caterina would have been free to dispose of her wealth in case she did not have any children; only in the event of her intestate death without children assets should have been split between Antonio's and Caterina's kinsmen.

\section{FEMALE AGENCY}

To what extent did female inheritance enable women to manage their own assets? We have seen that the testators' intentions were not always respected; even when they were, when women actually inherited family property, were they able to dispose of their wealth? The cadastral and notarial sources shed a light on female agency, on women fiscally responsible for their possessions, on their capability to act in contracts and decide how to manage goods. It is not surprising that widowhood became for several women the age of wider economic autonomy; scholars have highlighted this phenomenon in various other cities. ${ }^{69}$ In what follows I will therefore examine agency of daughters and wives, usually less studied as they are more difficult to trace in the sources.

Cadastral registers mention a huge number of young unmarried women who inherited family wealth as only daughters: most of them later disappeared from the sources due to marriage, their inheritance share transferred to husbands thanks to the fact that the law did not regulate the management of non-dotal assets. The status of solo female was thus often temporary; nevertheless, there are significant examples of unmarried women who carried on an independent life, as we have seen that Giorgia Alpino did. These women usually did not inherit huge amounts of land, but always had their own house and often an economic activity or income to sustain themselves. Giorgia inherited her father's tavern; her neighbour Alaxona de Burgo lived on her own at least from 1349 to 1391, sole owner of a house, four iornate of land, but most of all of 50 sheep and 13 cows, her family being cattle breeders and butchers. ${ }^{70}$ These women could take part in contracts on their own and they did, without the intervention of any kind of guardians, not prescribed by the law. ${ }^{71}$

However, not only was living as solo females definitely less likely at a higher social and economic level, but the chances of prolonging this condition diminished since the late 14th century. After Bertino Zucca died in the 1420s, his family split into three separate households: his widow remained in the family house, whilst the rest of the patrimony (more than 70 iornate of land) was equally divided between the children Bonifacio and Elena who moved to contiguous houses. ${ }^{72}$ Despite her brother's protest, Elena clearly got much more than the average amount of a dowry and was still living on her own in 1430, when we find her lending money to a man from a nearby town without the involvement of any other man. ${ }^{73}$ Then she disappeared from the sources, due to marriage or death. Similar examples become much rarer in the 15th century.

Studies on demography, sexual behaviours and authority intervention in late medieval Piedmont f. $91 \mathrm{r}$.

71. On guardianship Feci 2004; several examples of women acting without guardians are reported in Petti Balbi Guglielmotti 2012.

72. ASCT, coll. V, vol. 1048, fos. 16r, 23r-24v, 113r-115r.

73. AAT, sez. VI, prot. 29 , fos. $39 \mathrm{v}-40 \mathrm{r}$. 
ascribed this decline in female household heads to a change in sexual customs connected to the post Black Death population fall. ${ }^{74} \mathrm{~A}$ series of plagues and the subsequent loosening of demographic pressure led to a lower marriage age, thus the decline in solo females, and to an increase in remarriage, hence a parallel decline in numbers of widows. According to this research, these transformations determined a reinforcement of the patriarchal society, women being increasingly under male control and protection, a picture corresponding to the general image of decline of women's status in Italy since the late 14 th century ${ }^{75}$ However, other elements need to be taken into consideration. Firstly, a break from the plague, which still hit Turin in the early 15th century, but gradually decreased until new waves started in the 1480s, meant that, due to a lower male mortality, fiscal entries were more likely to be put in men's names. Secondly, these data are probably not enough to infer a "patriarchalization» of society, as women could maintain a certain degree of agency even when married or remarried.

Women could experience a limited margin of agency within their new household, taking part in the management of their own or family assets and incomes, being responsible for minor children and later freely disposing of their wealth in wills. ${ }^{76}$ As previously anticipated, the da Gorzano provide a remarkable example of how women could be involved in economic affairs under the control of the kinship group: several wives and later widows appeared not only in fiscal entries, but also selling property and lending money, alone or jointly with their husbands, acting as guardians for their children of both sexes and sometimes even for nephews. ${ }^{77}$ What is striking in this respect is that they never required a guardian themselves, even when they were dealing with family possessions; most contracts of the da Gorzano, though, involved kin as actors, witnesses or notaries, so to an extent these women were allowed wider agency, but always within the boundaries of the kinship group.

As far as agency after marriage was concerned, it is particularly interesting to note that, while the

74. Comba 1986, p. 552-559.

75. Cohn 1996.

76. Similar situations in the essays collected in Petti Balbi Guglielmotti 2012.

77. See above n. 47. number of solo female household heads decreased since the late 14th century, at the same time a higher proportion of the women listed in the cadastral registers were married, sometimes jointly enrolled with their husbands, more often as the only holders of the fiscal statement. Independent female entries included the woman's personal property beyond the dowry in case husbands had a separate one, as for Caterina da Pavarolo, who owned in 1392 more than 30 iornate of land and incomes from rents, for an overall value of 25 lire, almost as much as her husband Vittorio da Castronovo had. ${ }^{78}$ We can be sure these possessions were Caterina's inheritance, because she was already married and dowered when she pleaded with the prince of Savoy-Achaea in order to obtain her share of paternal wealth from her brother and in-laws. As in this case, non-dotal female assets frequently included landed property and money, more rarely houses.

When wives listed all family possessions and husbands did not appear in the source with a separate entry it is most likely that women were acting on their husband's behalf, an hypothesis further supported by the occasional use of the formula coniuncta persona. These cases dramatically increased since the 1430s, when almost a third of the overall women recorded in the cadastre were wives; a similar proportion appears in the following decades, until in 1488 joint fiscal entries of husbands and wives prevailed. The emergence of this types of statement is indicative of the role women might have played even when married, entrusted with tasks which presumably entailed more than just listing assets in front of the notary. Women acted in contracts and were increasingly involved also in their husbands' economic transactions, often because part of the family assets were theirs; they were subsequently chosen as sole guardians of children, the main reference being the household rather than possible agnates.

The remarkable growth of couples' joint fiscal statements in the late 15 th century despite the increasing number of heiresses provides an additional clue of the fact that women's assets were eventually included in their husbands' patrimo-

78. ASCT, coll. V, vol. 1038, f. 75r; vol. 1133, f. 60r. 
nies. In this respect the 1489 council provision resulted from the intention not simply of defending women's rights, but rather of supporting husbands' attempts to control inheritances. Fathers also contributed to this change, by choosing to build stronger ties with their sons-in-law rather than keeping closer to their kin, a decision driven by the wider social transformations and the attractiveness of these new citizens, often provided with capitals or lawyers in the local university or employed in the Savoy administration.

A few years later than the council provision, in 1500, a dispute between brother and sister provides evidence of the attempt of husbands to take over wives' assets: Antonina Calcagno and her husband claimed her half portion of paternal inheritance (more than 400 florins and half the family house), arguing that her parents had promised it to her, though without referring to a will or deed whatsoever. ${ }^{79}$ It is striking in this respect that Antonina was acting with her husband, who did not have any direct rights on the inheritance.
Although her brother Oberto, a priest, objected that she had already received 200 florins for her dowry, the judge admitted the couple's request and established equal division of possessions and care of their widowed mother. The clerical status of Oberto excluded him to an extent from full rights over family assets, but such a demand would have been unfeasible a century earlier considering the importance of the Calcagno kinship group in the elite and the condition of female rights, all but organized by law. This would have been impossible without the long process of the previous decades - in which fathers and husbands had shown preference for daughters and wives in a context of loosening of kinship ties - nor without the radical renewal of the elite, which marked the end of a social and political world ruled by a stable group of lineages. Subsequent developments in women's access to property need therefore to be examined in the light of the peculiar political structures of Turin,${ }^{80}$ which did not see the affirmation of a patriciate as other cities in northern Italy.

\section{Bibliography}

Arcangeli 2012 = L. Arcangeli, Ragioni di stato e ragioni di famiglia: strategie successorie dell'aristocrazia milanese tra Quattro e Cinquecento (Visconti, Trivulzio, Borromeo), in Chauvard - Bellavitis - Lanaro 2012, p. 447-469.

Barale 2011 = L. Barale (ed.), Testamenti chieresi del '400, Asti, 2011.

Barbero 1995 = A. Barbero, Un'oligarchia urbana. Politica ed economia a Torino fra Tre e Quattrocento, Rome, 1995.

Barbero 2014 = A. Barbero, The feudal principalities: the west (Monferrato, Saluzzo, Savoy, Savoy-Acaia), in Gamberini - Lazzarini 2014, p. 177-196.

Barbero - Pene Vidari 1997 = A. Barbero, G.S. Pene Vidari, Torino sabauda. Dalle lotte di parte e dalle congiure antisabaude a un nuovo equilibrio sociale e istituzionale, in Comba 1997, p. 211-257.

Bellomo 1961 = M. Bellomo, Ricerche sui rapporti patrimoniali tra coniugi. Contributo alla storia della famiglia medievale, Milan, 1961.

Bezzina 2015 = D. Bezzina, Artigiani a Genova nei secoli XIIXIII, Florence, 2015.

Bizzarri 1933 = D. Bizzarri, Gli Statuti del Comune di Torino del 1360, Turin, 1933.

Bordone - Fissore $1997=$ R. Bordone, G.G. Fissore, Caratteri della società urbana fra XI e XII secolo, in Sergi 1997, p. 465-515.

Calvi 1994 = G. Calvi, Il contratto morale. Madri e figli nella Toscana moderna, Rome, 1994.

Calvi 2004 = G. Calvi (ed.), Innesti. Donne e genere nella storia sociale, Rome, 2004.

Calvi - Chabot 1998 = G. Calvi, I. Chabot (eds.), Le ricchezze delle donne. Diritti patrimoniali e poteri familiari in Italia (XIII-XIX secc.), Turin, 1998.

Cammarosano 1977 = P. Cammarosano, Les structures familiales dans les villes de l'Italie communale, XII -XIV siècles, in G. Duby, J. Le Goff (eds.), Famille et parenté dans l'Occident médiéval, Rome, 1977, p. 181-194.

Casiraghi - Artifoni - Castelnuovo 1997 = G. Casiraghi, E. Artifoni, G. Castelnuovo, Il secolo XIII: apogeo e crisi, in Sergi 1997, p. 659-714.

Cavaciocchi $1990=$ S. Cavaciocchi (ed.), La donna nell'economia, secc. XIV-XVIII, Florence, 1990.

Cavallo 1998 = S. Cavallo, Proprietà o possesso? Composizione e controllo dei beni delle donne a Torino (1650-1710), in Calvi - Chabot 1998, p. 187-207.

79. AST, Sez. riunite, Pergamene antiche, n. 325.

80. A first attempt in Cavallo 1998. 
Against the tide. Female property and political shift in late medieval Turin

164 Marta Gravela

Chabot 1996 = I. Chabot, Risorse e diritti patrimoniali, in A. Groppi (ed.), Storia delle donne in Italia. II. Il lavoro delle donne, Rome-Bari, 1996, p. 47-70.

Chabot 1998 = I. Chabot, La loi du lignage. Notes sur le système successoral florentin (XIV $-X V^{e}-X V I I^{e}$ siècles), in Clio. Histoire, Femmes et Sociétés, 7, 1998, p. 51-72.

Chabot $2006=\mathrm{I}$. Chabot, Richesses des femmes et parenté dans l'Italie de la Renaissance. Une relecture, in ChabotHayez - Lett 2006, p. 263-290.

Chabot 2010 = I. Chabot, Il governo dei padri: lo stato fiorentino e la famiglia tra XIV e XV secolo, in J. Boutier, S. Landi, O. Rouchon (eds.), Firenze e la Toscana. Genesi e trasformazioni di uno stato (XIV-XIX secolo), Florence, 2010, p. 195-212.

Chabot 2011 = I. Chabot, La dette des familles. Femmes, lignage et patrimoine à Florence aux $X I V^{e}$ et $X V^{e}$ siècles, Rome, 2011.

Chabot - Hayez - Lett 2006 = I. Chabot, J. Hayez, D. Lett (eds.), La famille, les femmes et le quotidien (XIVeXVIII siècle). Textes offerts à Christiane Klapisch-Zuber, Paris, 2006.

Chauvard - Bellavitis - Lanaro 2012 = J. F. Chauvard, A. Bellavitis, P. Lanaro (eds.), Fidéicommis. Procédés juridiques et pratiques sociales (Italie-Europe, Bas Moyen Âge - XVIII siècle), in MEFRM, 124-2, 2012, p. 321-728.

Chojnacki $2000=$ S. Chojnacki, Women and men in Renaissance Venice. Twelve essays on patrician society, Baltimore, 2000.

Cognasso 1914 = F. Cognasso (ed.), Documenti inediti e sparsi sulla storia di Torino, Pinerolo, 1914.

Cohn 1988 = S.K. Cohn Jr., Death and property in Siena, 1205-1800. Strategies for the afterlife, Baltimore-London, 1988.

Cohn 1996 = S. K. Cohn Jr., Women in the streets. Essays on sex and power in Renaissance Italy, Baltimore-London, 1996.

Comba 1986 = R. Comba, "Apetitus libidinis coherceatur». Strutture demografiche, reati sessuali e disciplina del comportamenti nel Piemonte tardo medievale, in Studi storici, 27, 1986, p. 529-576.

Comba $1997=$ R. Comba (ed.), Storia di Torino. II. Il basso medioevo e la prima età moderna (1280-1536), Turin, 1997.

Crouzet-Pavan 1992 = É. Crouzet-Pavan, "Sopra le acque salse». Espaces, pouvoir et société à Venise à la fin du Moyen Âge, Rome, 1992.

Decreta Sabaudiae = Decreta Sabaudiae Ducalia, Turin, 1477.

Duboin 1831 = F.A. Duboin (ed.), Raccolta delle leggi, editti, manifesti della Real Casa di Savoia, VII, Turin, 1831.

Duval 2018 = S. Duval, Women and wealth in late medieval Pisa (c. 1350-1420), in MEFRM, 130-1, 2018 (in this issue).

Feci 2004 = S. Feci, Pesci fuor d'acqua. Donne a Roma in età moderna: diritti e patrimoni, Rome, 2004.

Ferente $2014=\mathrm{S}$. Ferente, Women and the State, in Gamberini - Lazzarini 2014, p. 345-367.

Fisher 2009 = C.M. Fisher, Guardianship and the rise of the Florentine State, 1368-93, in A. Bellavitis, I. Chabot (eds.), Famiglie e poteri in Italia tra Medioevo ed età moderna, Rome, 2009, p. 265-282.
Gamberini 2017 = A. Gamberini, «I piedi e le tibie» dello stato: gli officiali. Legittimazione e costruzione identitaria di un nuovo ceto politico nelle parole di Uberto Decembrio, in A. Gamberini (ed.), La mobilità sociale nel medioevo italiano. II. Stato e istituzioni (secoli XIV-XV), Rome, 2017, p. 99-115.

Gamberini - Lazzarini 2014 = A. Gamberini, I. Lazzarini (eds.), The Italian Renaissance State, Cambridge, 2014.

Gravela $2014=$ M. Gravela, Comprare il debito della città. Élite politiche e finanze comunali a Torino nel XIV secolo, in Quaderni storici, 147, 2014, p. 743-773.

Gravela 2017a = M. Gravela, Il corpo della città. Politica e parentela a Torino nel tardo Medioevo, Rome, 2017.

Gravela $2017 \mathrm{~b}=$ M. Gravela, The primacy of patrimony. Kinship strategies of the political elite of Turin in the Late Middle Ages (1340-1490), in Continuity and Change, 32-3, 2017, p. 293-321.

Guerra Medici 1996 = M.T. Guerra Medici, L'aria di città Donne e diritti nel comune medievale, Naples, 1996.

Guzzetti 1998 = L. Guzzetti, Le donne a Venezia nel secolo XIV: uno studio sulla loro presenza nella società e nella famiglia, in Studi veneziani, 35, 1998, p. 15-88.

Howell 1988 = M.C. Howell, Citizenship and gender: women's political status in northern medieval cities, in M.C. Erler, M. Kowaleski (eds.), Women and power in the Middle Ages, Athens-London, 1998, p. 37-60.

Hughes 1975 = D.O. Hughes, Domestic ideals and social behavior: evidence from medieval Genoa, in C.E. Rosenberg (ed.), The family in history, Philadelphia, 1975, p. 115143.

Hughes 1978 = D.O. Hughes, From brideprice to dowry in Mediterranean Europe, in Journal of Family History, 3-3, 1978, p. 262-296.

Kirshner $2004=\mathrm{J}$. Kirshner, Genere e cittadinanza nelle città-stato del Medioevo e del Rinascimento, in Calvi 2004, p. $21-38$.

Kirshner 2006 = J. Kirshner, Christiane Klapisch-Zuber, un regard de Chicago, in Chabot - Hayez - Lett 2006, p. 79-88.

Kirshner 2015 = J. Kirshner, Marriage, dowry, and citizenship in late medieval and Renaissance Italy, Toronto, 2015.

Kirshner - Molho 1978 = J. Kirshner, A. Molho, The dowry fund and the marriage market in early Quattrocento Florence, in The Journal of Modern History, 50-3, 1978, p. 403-438.

Klapisch-Zuber 1985 = C. Klapisch-Zuber, Women, family, and ritual in Renaissance Italy, Chicago, 1985.

Kuehn 1991 = T. Kuehn, Law, family, and women. Toward a legal anthropology of Renaissance Italy, Chicago-London, 1991.

Kuehn 1999 = T. Kuehn, Figlie, madri, mogli e vedove: donne come persone giuridiche, in Seidel Menchi - Jacobson Schutte - Kuehn 1999, p. 431-460.

Kuehn 2012 = T. Kuhen, Dos non teneat locum legittime: Dowry as a woman's inheritance in Early Quattrocento Florence, in P. Andersen, D. Tamm (eds.), Law and marriage in Medieval and Early Modern Times, Copenhagen, 2012, p. 231-248.

Kuehn 2015 = T. Kuehn, Gender and law in Milan, in A. Gamberini (ed.), A companion to late medieval and 
early modern Milan. The distinctive features of an Italian State, Leiden-Boston, 2015, p. 406-431.

Lanaro 2012 = P. Lanaro, Fedecommessi, doti, famiglia: la trasmissione della ricchezza nella Repubblica di Venezia (XV-XVIII secolo). Un approccio economico, in Chauvard - Bellavitis - Lanaro 2012, p. 519-531.

Leverotti 1994 = F. Leverotti, "Governare a modo e stillo de" Signori...». Osservazioni in margine all'amministrazione della giustizia al tempo di Galeazzo Maria Sforza duca di Milano (1466-76), Florence, 1994.

Libri consiliorum 2006 = M. Baima (ed.), Libri consiliorum 1387-1389. Trascrizione e regesto degli Ordinati comunali, Turin, 2006.

Mayali 1987 = L. Mayali, Droit savant et coutumes : l'exclusion des filles dotées, XII $-X V^{e}$ siècles, Frankfurt am Main, 1987.

Menzinger $2012=\mathrm{S}$. Menzinger, La donna medievale nella sfera pubblica: alcune riflessioni in tema di cittadinanza nel panorama degli studi storico-giuridici, in M. Davide (ed.), La condizione giuridica delle donne nel medioevo, Trieste, 2012, p. 117-143.

Meriggi $2004=$ M. Meriggi, Privato, pubblico, potere, in Calvi 2004, p. 39-51.

Molho 1994 = A. Molho, Marriage alliance in late medieval Florence, Cambridge (Mass.), 1994.

Mongiano 1990 = E. Mongiano, Ricerche sulla successione intestata nei secoli XVI-XVIII: il caso degli Stati Sabaudi, Turin, 1990.

Muzzarelli 1998 = M.G. Muzzarelli, Des poissons difficiles à pêcher, in Clio. Histoire, Femmes et Sociétés, 8, 1998, p. 95-122.
Niccolai 1940 = F. Niccolai, La formazione del diritto successorio negli statuti comunali del territorio lombardo-tosco, Milan, 1940.

Pene Vidari 1986 = G.S. Pene Vidari, Dote, famiglia e patrimonio fra dottrina e pratica in Piemonte, in G. Lazzi (ed.), La famiglia e la vita quotidiana in Europa dal '400 al '600. Fonti e problemi. Atti del Convegno internazionale, Milano, 1983, Rome, 1986, p. 109-121.

Petti Balbi - Guglielmotti 2012 = G. Petti Balbi, P. Guglielmotti (eds.), Dare credito alle donne. Presenze femminili nell'economia tra medioevo ed età moderna. Convegno internazionale di studi, Asti, 2010, Asti, 2012.

Rossi $2010=$ M.C. Rossi (ed.), Margini di libertà. Testamenti femminili nel Medioevo, Caselle di Sommacampagna (Vr), 2010.

Seidel Menchi - Jacobson Schutte - Kuehn $1999=$ S. Seidel Menchi, A. Jacobson Schutte, T. Kuehn (eds.), Tempi e spazi di vita femminile tra medioevo ed età moderna, Bologna, 1999 (Annali dell'Istituto storico italo-germanico in Trento, 51).

Sergi $1997=$ G. Sergi (ed.), Storia di Torino. I. Dalla preistoria al comune medievale, Turin, 1997.

Statuti 1981 = Torino e $i$ suoi statuti nella seconda metà del Trecento, Turin, 1981.

Storti Storchi 1985 = C. Storti Storchi, Aspetti della condizione giuridica dello straniero negli statuti lombardi dei secoli XIV-XV, in Archivio Storico Lombardo, 111,1985 , p. 9-66. 